\title{
Palliative care: views of patients and their families
}

\author{
Irene Higginson, Angela Wade, Mark McCarthy
}

Abstract
Objective-To investigate the current problems and needs of terminally ill cancer patients and their family members, and to discover their views of hospital, community, and support team services.

Design-Prospective study of patients and families by questionnaire interviews in the patients' homes.

Setting-Inner London and north Kent (London suburbs).

Subjects-65 Patients, each with a member of their family or a carer.

Main outcome measures - Ratings of eight current problems and ratings and comments on three services-hospital doctors and nurses, general practitioners and district nurses, and the support team staff-obtained after a minimum of two weeks' care from palliative care support teams.

Results-Effect of anxiety on the patient's nearest carer and symptom control were rated as the most severe current problems by both patients and families; a few patients and families identified other severe problems. Families' ratings of pain control, symptom control, and effect of anxiety on the patient were significantly worse than the patients' ratings $(p<0.05)$. Support teams received the most praise, being rated by $58(89 \%)$ patients and $59(91 \%)$ of family members as good or excellent. General practitioners and district nurses were rated good or excellent by $46(71 \%)$ patients and $46(71 \%)$ family members, but six $(9 \%)$ in each group rated the service as poor or very bad, and ratings in the inner London district were significantly worse than those in the outer London district. Hospital doctors and nurses were rated good or excellent by $22(34 \%)$ patients and $35(54 \%)$ of family members, and 14 $(22 \%)$ patients and $15(23 \%)$ family members rated this service as poor or very bad. Negative comments referred to communication (especially at diagnosis), coordination of services, the attitude of the doctor, delays in diagnosis, and difficulties in getting doctors to visit at home. Family members were more satisfied with the services than were patients.

Conclusions-Palliative care needs to include both the patient and family because the needs of the family may exceed those of the patient. Support teams and some hospital and community doctors and nurses met the perceived needs of dying patients and families, but better education and organisation of services are needed.

\section{Introduction}

Care of terminally ill patients and their families places many difficult demands on the health services. Palliative treatment of such patients has grown rapidly in the past decade, ${ }^{2}$ starting with inpatient hospices and expanding to include support teams in hospitals, hospices, and the community. ${ }^{34}$ Most patients wish to die at home or to remain at home for as long as possible, 5 though many do not want to lose contact with the hospital and community services they already know. Support teams have aimed at providing extra help and advice for terminally ill patients and their families in cooperation with the doctors and nurses already involved in their care. ${ }^{6}$

There are several models of support team, ranging from just one or two nurses to large teams with medical, social work, administrative, and volunteer support. ${ }^{47}$ There has been no prospective study of the views of patients and their relatives about terminal care services in Britain since the work of Hinton and Parkes at St Christopher's Hospice, Sydenham, about 10 years previously. ${ }^{89}$ Disappointing results of community based hospice care were recently obtained in the United States, ${ }^{10}$ but these results are not directly relevant to Britain because the community services are so different. ${ }^{411}$

To evaluate palliative care, including care by support teams, and to assess the current needs and problems of terminally ill patients we interviewed patients who were in the care of two community based support teams, together with members of their families, and we collected ratings and comments about hospital, community, and support team services.

\section{Subjects and methods \\ Support teams}

One team was based in Bloomsbury Health District in inner London and the other was in south Bromley, Kent, an outer London suburb. The Bloomsbury team has operated from 1982 and the south Bromley team from 1984. Both teams are multidisciplinary, with doctors, nurse specialists, a social worker, a secretary or administrator, and volunteers. The Bloomsbury team had four regular volunteers; the south Bromley team had over 30, with a coordinator, training programme, and individual contracts for volunteers. Neither team was attached to a hospice, nor did they have dedicated terminal care beds. Both had offices within the grounds of a district general hospital and worked with patients and families at home and in several local hospitals, liaising with other professionals to assist and advise on the care of terminally ill patients and their families. Their aims were those of the hospice movement: to control symptoms, to give support and advice, to coordinate care, to meet practical and financial needs, and to provide education and bereavement support when necessary.

\section{Patients and family members}

The researcher (IH) contacted patients and their nearest family member or friend, usually the spouse, between two and four weeks after the first assessment by a support team and asked if they would be prepared to take part in the study. The researcher emphasised that the interviews were confidential and completely separate from any of the services the patients received. The general practitioner and the support team were 


\begin{tabular}{|c|c|c|}
\hline Item & Definition & Range (best; worst) \\
\hline Pain control & Effect of pain(s) on the patient & $\begin{array}{l}\text { None; severe and continuous, unable to concentrate, eat, } \\
\text { sleep, or describe }\end{array}$ \\
\hline Symptom control & Effect of symptom(s) on the patient & $\begin{array}{l}\text { None; severe and continuous, unable to concentrate, eat, } \\
\text { sleep, or describe }\end{array}$ \\
\hline Patient anxiety & Effect of anxiety on the patient & $\begin{array}{l}\text { None; severe and continuous, unable to concentrate, eat, } \\
\text { sleep, or describe }\end{array}$ \\
\hline Family anxiety & $\begin{array}{l}\text { Effect of anxiety on the family (the patient's nearest } \\
\text { carer) }\end{array}$ & $\begin{array}{l}\text { None; severe and continuous, unable to concentrate, eat, } \\
\text { sleep, or describe }\end{array}$ \\
\hline Practical & $\begin{array}{l}\text { Further need for practical aids at home, reflecting the } \\
\text { difficulty for patient and carer without aids }\end{array}$ & None needed; patient incapacitated without basic aids \\
\hline Wasted time & $\begin{array}{l}\text { Amount of patient's time lost for tests which could have } \\
\text { been avoided, the patient not wishing to attend }\end{array}$ & No time lost; several days wasted \\
\hline $\begin{array}{l}\text { Communication of support team with } \\
\text { patient and family }\end{array}$ & $\begin{array}{l}\text { Depth of information given to patient and carer, when } \\
\text { they require this, from support team members }\end{array}$ & $\begin{array}{l}\text { Full information with any changes explained; avoiding } \\
\text { answering all questions and not visiting }\end{array}$ \\
\hline $\begin{array}{l}\text { Communication of professionals with } \\
\text { patient and family }\end{array}$ & $\begin{array}{l}\text { Depth of information given to patient and carer, when } \\
\text { they require this, from other professionals (including } \\
\text { general practitioner, district nurse, social worker, } \\
\text { hospital staff) }\end{array}$ & $\begin{array}{l}\text { Full information with any changes explained; avoiding } \\
\text { answering all questions and not visiting }\end{array}$ \\
\hline
\end{tabular}

notified of the date and time of interview, and the researcher confirmed that they were happy for the visit to take place. The study was approved by local ethics committees.

\section{Assessments}

Patients and their family members were interviewed at home, in separate rooms, by the researcher and a trained volunteer. Data were collected with standard questionnaires and included age, main occupation (previous occupations if retired), and questions relating to current problems. For these questions we chose eight items of care, including symptoms, anxieties, communication, and service needs (table I), previously identified as problems for terminally ill patients that could be assessed in one short interview. ${ }^{12-14}$ Each item was rated over the past week on five point scales $(0=$ best, $4=$ worst $)$, using definitions given in the questionnaire for each point. Comments and ratings on health services were also obtained. Patients and family members commented freely, and then chose one of five ratings (excellent, good, ok, poor, very bad) or chose to make no formal rating ${ }^{14}$ in relation to three aspects of the health services: hospital doctors and nurses; general practitioners and district nurses; and support team staff. When possible we attempted follow up interviews four to six weeks later to repeat the assessments of current problems and of the health services.

\section{Analyses}

Mean and median ratings (and interquartile ranges) for the eight problem items were calculated. We tested the differences between patients' and family members' ratings using the Wilcoxon signed ranks test. Spearman and Pearson correlations ${ }^{15}$ were used to compare patients' and family members' totalled ratings. To investigate agreement over their ratings we used Cohen's $x$, which shows the proportion of agreement controlling for chance $(0=$ no agreement above chance;

TABLE II-Ratings from patients and their family members for care in previous week and percentage of ratings indicating no problem (score 0 )

\begin{tabular}{|c|c|c|c|c|c|c|c|}
\hline & \multicolumn{3}{|c|}{ Patient's rating } & \multicolumn{3}{|c|}{ Family member's rating } & \multirow{2}{*}{$\begin{array}{c}\text { Wilcoxon } \\
Z \\
\text { (paired } \\
\text { ratings) }\end{array}$} \\
\hline & Mean & $\begin{array}{c}\text { Median } \\
\text { (interquartile } \\
\text { range) }\end{array}$ & $\begin{array}{c}\text { No } \\
\text { problem } \\
(\%)\end{array}$ & Mean & $\begin{array}{c}\text { Median } \\
\text { (interquartile } \\
\text { range) }\end{array}$ & $\begin{array}{c}\text { No } \\
\text { problem } \\
(\%)\end{array}$ & \\
\hline Pain control & $1 \cdot 13$ & $1(0-2)$ & $32 \cdot 1$ & $1 \cdot 45$ & $1 \cdot 5(0-2)$ & $32 \cdot 8$ & $-2 \cdot 54^{\star}$ \\
\hline Symptom control & $1 \cdot 36$ & $1(0-2)$ & $29 \cdot 1$ & 1.85 & $2(1-3)$ & $16 \cdot 9$ & $-2 \cdot 77^{\star \star}$ \\
\hline Patient anxiety & 0.79 & $0(0-1)$ & $57 \cdot 1$ & 1.51 & $1 \quad(0-3)$ & $33 \cdot 3$ & $-4 \cdot 26^{\star \star \star}$ \\
\hline Family anxiety & 1.46 & $1(0-2)$ & $27 \cdot 1$ & 1.84 & $2(1-3)$ & $17 \cdot 2$ & $-1.76 \mathrm{NS}$ \\
\hline Practical & $0 \cdot 18$ & $0(0-0)$ & $87 \cdot 1$ & $0 \cdot 22$ & $0 \quad(0-0)$ & $83 \cdot 1$ & $-1.01 \mathrm{NS}$ \\
\hline Wasted time & 0.09 & $0(0-0)$ & $95 \cdot 3$ & $0 \cdot 17$ & $\begin{array}{ll}0 & (0-0)\end{array}$ & $89 \cdot 2$ & $-0.89 \mathrm{NS}$ \\
\hline \multicolumn{8}{|l|}{ Communication from: } \\
\hline Support team & 0 & 0 & $100 \cdot 0$ & $0 \cdot 11$ & $\begin{array}{ll}0 & (0-0)\end{array}$ & $92 \cdot 3$ & $-1.82 \mathrm{NS}$ \\
\hline Other professionals & 0.07 & $0(0-0)$ & $95 \cdot 1$ & $0 \cdot 13$ & $\begin{array}{ll}0 & (0-0)\end{array}$ & $88 \cdot 5$ & $-1.60 \mathrm{NS}$ \\
\hline
\end{tabular}

NS $=$ Not significant

${ }^{\star} \mathrm{p}<0 \cdot 05,{ }^{\star} \mathrm{p}<0 \cdot 01,{ }^{\star \star} \mathrm{p}<0 \cdot 0005$, Wilcoxon matched pairs signed ranks test between patients' and members' ratings.
$1=$ complete agreement $).{ }^{16}$ Differences in service ratings, stratified by patient and family member, between the Bloomsbury and south Bromley districts were assessed by the $\chi^{2}$ test (giving conservative estimates of significance)..$^{15}$

\section{Results}

INTERVIEWS

We interviewed 65 patients (all of whom had cancer) and their nearest carer, who was almost always a member of their family; the term "family member" will be used subsequently ( 31 wives $(48 \%), 17$ husbands (26\%), six daughters $(9 \%)$, four sisters $(6 \%)$, four friends $(6 \%)$, three sons (5\%)). All family members were living with the patients or visited them at least daily. Median time from the first interview to the patient's death was six weeks (range 1 to 74 weeks, three patients still living). Mean age of patients was 66 years (range 32 to 83 years) and of family members was 60 (22 to 82) years. Social class distribution was: I 3\% (two families), II 15\% (10), III non-manual $22 \%$ (14), III manual 32\% (21), IV 17\% (11), long term unemployed $8 \%$ (five), others $3 \%$ (two).

\section{RATINGS OF EIGHT CURRENT PROBLEMS}

Table II shows the ratings at the first interview separately for patients and family members. Most problems occurred in the patient and family items (family anxiety, symptom control, patient anxiety, pain control), but the mean score never exceeded 2 (moderate rroblems); for each item only one patient scored 4 (worst). The four other items showed almost complete achievement, most ratings being 0 (no problem). Communication with the support team was never identified as a problem by patients. In the second interview mean scores were similar or slightly lower.

Three items (pain control, symptom control, patient anxiety) were given a higher rating by family members than by patients $(\mathrm{p}<0.05$, two tailed test). Family anxiety showed a tendency $(p=0.08)$ for higher ratings from family members.

The ratings of patients and family members for the totalled scores were correlated (Spearman $\varrho=0.69$; Pearson $\mathrm{r}=0.71 ; \mathrm{p}<0.005$, but family members' ratings were higher (indicating more problems) than patients' ratings (Wilcoxon $Z=-4.09 \mathrm{p}<0.0005$ ). Variations between patients' and family members' ratings were not consistent, nor were they related to any particular category of family member. In the most extreme case a husband rated 10 while the patient rated 1 .

\section{COMMENTS AND RATINGS OF HEALTH SERVICES} Hospital doctors and nurses

There was a mixture of ratings and comments on hospital services. Positive comments were general 


\begin{tabular}{|c|c|c|c|c|c|c|c|c|c|c|c|c|}
\hline & \multicolumn{2}{|r|}{ Excellent } & \multicolumn{2}{|r|}{ Good } & \multicolumn{2}{|r|}{ OK } & \multicolumn{2}{|r|}{ Poor } & \multicolumn{2}{|r|}{ Very bad } & \multicolumn{2}{|c|}{ No comment } \\
\hline & Patient & Family member & Patient & Family member & Patient & Family member & Patient & Family member & Patient & Family member & Patient & Family member \\
\hline Hospital services & $6(9)$ & $12(18)$ & $16(25$ & $23(35)$ & $18(28)$ & $7(11)$ & $9(14)$ & $11(17)$ & $5(8)$ & $4(6)$ & $11(17)$ & $8(12)$ \\
\hline $\begin{array}{l}\text { General practitioners and } \\
\text { district nurses } \\
\text { Support team staff }\end{array}$ & $\begin{array}{l}13(20) \\
25(38)\end{array}$ & $\begin{array}{l}26(40) \\
36(55)\end{array}$ & $\begin{array}{l}33(51) \\
33(51)\end{array}$ & $\begin{array}{l}20(31) \\
23(35)\end{array}$ & $\begin{array}{l}8(12) \\
4(6)\end{array}$ & $\begin{array}{l}7(11) \\
2(3)\end{array}$ & $\begin{array}{l}3(5) \\
0\end{array}$ & $\begin{array}{l}3 \\
0\end{array}$ & $\begin{array}{l}3(5) \\
0\end{array}$ & $\begin{array}{l}3(5) \\
0\end{array}$ & $\begin{array}{ll}5 & (8) \\
3 & (5)\end{array}$ & $\begin{array}{ll}6 & (9) \\
4 & (6)\end{array}$ \\
\hline
\end{tabular}

TABLE IV-Assessment of palliative care given by general practitioners and district nurses. Values are numbers (percentages) of patients and family members combined

\begin{tabular}{lccccc}
\hline & Excellent & Good & OK & Poor/very bad & No comment \\
\hline Bloomsbury (inner London $)(n=70)$ & $12(17)$ & $25(36)$ & $13(19)$ & $11(16)$ & $9(13)$ \\
South Bromley (outer London $)(n=60)$ & $27(45)$ & $28(47)$ & $2(3)$ & $1(2)$ & $2(3)$ \\
\hline
\end{tabular}

("smashing," "caring," "kind") or specific ("I liked the doctor who broke bad news by holding my hand and stroking it"). Table III shows the ratings given by patients and family members. Although patients' and family members' ratings were correlated and just reached significant agreement above chance, the coefficients were low (Spearman $\varrho=0 \cdot 39, \mathrm{p}<0.001$; $x=0.30, p=0.05)$. Family members' ratings were significantly higher (that is, better) than patients' ratings (Wilcoxon $Z=-2 \cdot 00, \mathrm{p}<0.05$ ).

Negative comments related to three main issues. Communication with doctors and nurses was the subject most commonly mentioned in $16(25 \%)$ patients and $17(26 \%)$ family members) and was usually related to previous rather than current difficulties-for example, "The ward sister told me abruptly, in front of my wife, that I had two months to live"; "The consultant sat on the end of the bed, swung his legs and said 'Well, you've got cancer.'" Patients and family members found it difficult to ask questions -for example, "Hospital doctors stand there with information in their head and expect you to read their mind. Very high and mighty, one or two of them." Some patients and family members understood that their doctors had difficulty dealing with aspects of death and dying: "The doctors were good but too glib. To surgeons, as I'm dying I'm a failure. I often embarrass them." Greater honesty would have been preferred: "They were a bit optimistic over the nerve block; they said very confidently it would work . . . it would have been better to be more honest." Two patients said they had not been told what was wrong with them in hospital.

Coordination of services was commented on by 11 (17\%) patients and seven (11\%) family members. Their complaints included past delays in the outpatient department or waiting for ambulances and ill informed doctors and nurses. Overworked staff was the third issue eliciting negative comment. Doctors and nurses were described by five subjects as "too busy to have time to care." One family member suggested that "there should be more nursing assistants to deal with the bed making, etc, and registered nurses might do better to circulate more slowly rather than bustling between one demanding patient and the next, and overlooking the quiet patients."

\section{General practitioners and district nurses}

General practitioners and district nurses were given better ratings than were hospital doctors and nurses. Comments referred to sympathy, professionalism, friendliness, and willingness to visit and discuss problems. Table III shows the ratings given by patients and family members. Patients' and family members' ratings were correlated (Spearman $\varrho=0.62, p<0.0005$ ) and showed significant agreement $(x=0.45, p<0.05)$. Family members tended to give higher ratings than patients.
Negative comments related to four main issues: nine patients (14\%) did not like the attitude of their doctors ("writes the prescription before you have sat down"; "gives amoxyl for everything"); five (8\%) complained of delays in diagnosis or referral; two (3\%) had problems getting home visits and three $(5 \%)$ with out of hours care and deputising services; and two (3\%) thought that their general practitioner was too old. There was little negative comment about district nurses.

\section{Support team staff}

The support teams were given the most high ratings, with high praise for communication, symptom control, practical and financial help, general support, and out of hours care. Table III shows the ratings given by patients and family members. No ratings were usually given when patient or family member thought that they had not known the team long enough to comment. Patients' and family members' ratings were correlated (Spearman $\mathrm{Q}=0.35, \mathrm{p}<0.01$ ) and showed agreement above chance $(x=0.16, p<0.05)$, but again the coefficients were low. A tendency to higher ratings from family members did not reach significance (Wilcoxon $\mathrm{Z}=-1 \cdot 69, \mathrm{p}=0 \cdot 09$ ).

There were only six negative comments. These were on miscellaneous matters and no general conclusions can be drawn, though two family members thought that the patients had been upset after team visits, and one patient believed that the team was not supporting her desire for euthanasia.

\section{Second interviews}

Only 12 second interviews were completed; many patients had died or were close to death; others said they had nothing further to add. The comments and proportions of the different ratings were similar to those on the first interviews.

\section{RATINGS FOR BLOOMSBURY AND SOUTH BROMLEY}

Ratings for general practitioners and district nurses were different in Bloomsbury and south Bromley. Patients and family members in south Bromley gave better ratings (table IV; $\chi^{2}=22 \cdot 71, \mathrm{df}=3, \mathrm{p}<0.005$, excluding no comments). There were no significant differences in ratings of hospital and support staff in the two areas.

\section{Discussion}

After two to four weeks of support team care, patients and family members had moderate problems with symptoms and anxieties. Few reported severe problems. This is in contrast to the findings of studies made before hospice care was available, which reported severe problems with all these aspects of care..$^{1417}$ Ideally we should know the condition of patients on referral to support teams to investigate this further, but in this study we thought that it would be unfair to interview patients at the point of referral as this would introduce another new face when they were first meeting the support team staff. A study using ratings from professionals showed that pain and symptoms improved during support team care. ${ }^{18}$

In an article for debate Gilley suggested that there is 
a "dying triad" where the carer or family member needs to be "emotionally held" during the nurturing of a dying patient. ${ }^{19}$ Our study lends support to this theory: when interviewed, patients and family members identified the effect of anxiety on the family as one of two most severe problems. Thus both the patient and the family must be cared for.

The agreements between family members' ratings and patients' ratings were disappointing and bring into question the use of family members' views as proxies for the views of patients, though it is normally assumed to be valid to do so (for example, in the American national hospice study $\left.^{10}\right)$. Family members rated symptoms and anxieties as more severe than did the patients. This may reflect their anxiety in a stressful situation, but the relation was not consistent and in a few instances family members rated symptoms and anxieties as less severe. When services were rated this trend was reversed: family members tended to be more satisfied. We do not know the reason for these discrepancies. They were not related to whether the family member was the spouse or to the sex of the family member; perhaps they are a reflection of individual personalities.

In assessing mood and awareness of dying Hinton found correlations between patients and spouses that were similar to those in our study, but he also found that mean ratings for mood, anxiety, attitude to illness, and awareness of dying were similar in patients and spouses. ${ }^{8}$ This difference may be due to the methods of assessment used in the two studies. Hinton interviewed the patients and family members separately, one after the other, and so was not blind to earlier results. $\mathrm{He}$ interpreted the information and made the ratings himself, whereas in our study the patient and the family member were asked to choose the most appropriate rating by separate interviewers. In a few instances the interviewers noted that they would not have made the assessment chosen by the patient or family member. If we had interpreted the interviews, as Hinton did, our results would have been different. We suggest that if the reports of patients or family members are required they must select the ratings themselves.

Our comparison of support team and other forms of care were weakened because we were not able to form a control group. Using cancer registries, Barnett and McCarthy managed to identify patients in inner London who had problems and who might have benefited from support team care but had not had the opportunity to receive it. ${ }^{20}$ They and many other researchers found it difficult, however, to identify patients before death using existing registries. ${ }^{21}$ Future comparative studies of terminal care will have to rely on the views of family members, and our study offers insight into the potential differences between the assessments of patients and family members so they can be considered alongside any findings. In clinical practice, awareness of these potential differences will assist in the overall assessment of patients and family members.

Comments and ratings of services were mixed for hospital doctors and nurses, better for general practitioners and district nurses, and much better for the support teams, indicating that support teams were a popular service that met the needs of patients and families. Two factors may have influenced this finding. Firstly, the patients had been in the care of support teams for only a short time, and they had known other services for much longer. It could be suggested that patients were still in their "honeymoon period" with the support teams. If we had interviewed them at a later stage, however, we should have missed a large number of patients who died within a few weeks of the onset of support care. In the few follow up interviews we were able to achieve the service ratings were similar and there was no reduction in the popularity of the support teams. Secondly, the patients as a group had contact with many different members of hospital and community staff. Some hospital and community services were described as excellent and others as poor or very bad. This, and the comments, suggests that some hospital and community staff offered good terminal care but others did not and were clearly in need of further training.

Surveying Scottish general practitioners, consultants, and newly qualified doctors, Doyle reported that communication with the dying was rated as important in training by fewer doctors than were either pain or symptom control. ${ }^{22}$ We found, however, that the comments from patients and families focused on communication more often than any other topic. The instances of praise show that patients and family members valued good communication and the professional staff who gave up their time to the dying. Communication problems were identified mainly around the time of diagnosis and treatment rather than later, suggesting that the support teams were performing well in this respect. The findings support the views of Maguire and Faulkner that "breaking bad news" needs to be improved by specific undergraduate training for doctors and nurses. ${ }^{23}$

In outer London the general practitioners and district nurses were rated as giving similar levels of satisfaction to the support teams, but ratings of the services in inner London varied widely. That $16 \%$ rated the service as poor or very bad is unacceptable. We suggest that this dissatisfaction may be related to a greater number of single handed general practices, a greater use of deputising services, difficulties in recruiting district nurses, and lack of commitment to coordinated care. These problems extend beyond the remit of individual training and require staff to examine the organisation of their services. In the right setting these problems in inner London can be overcome, as is shown by the fact that $53 \%$ of general practitioners and district nurses in inner London achieved good or excellent ratings.

We thank the members of the two support teams, Bloomsbury Support Team, London, and South Bromley Hospiscare, Kent, for their help and support during the study; Debbie Atkinson (medical student) and Pamela Sokel and Jan Lloyd (volunteers) for their assistance in the interviews; and, most importantly, the patients and family members who were willing to see us during a difficult time. We are grateful to Dr June Crown and the members of the department of community medicine, Bloomsbury Health District, for their useful suggestions in study design; Drs Jeffrey Tobias and Beryl Magrath, Sister Elizabeth Greenwood, and Miss Joyce Bell for their comments on a previous draft; and Help the Hospices, whose funding made this research possible.

1 Haines A, Booroff A. Terminal care at home: perspective from general practice. Br Med f 1986;292:1051-3.

2 Seale CF. What happens in hospices: a review of research evidence. Soc Sci Med 1989;28:551-9.

Working Group on Terminal Care. National terminal care policy. f $R$ Coll Gen Pract 1980;30:466-71.

Higginson I, McCarthy M. Evaluation of palliative care: steps to quality assurance? Palliative Medicine 1989;3:267-74.

Dunlop RJ, Davies RJ, Hockley JM. Preferred versus actual place of death: a hospital palliative care support team experience. Palliative Medicine 1989;3:197-201.

6 Copperman H. Domiciliary hospice care: a survey of general practitioners. I R Coll Gen Pract 1988;38:411-3.

7 Lu $B$. Terminal cancer care services: recent changes in regional inequalities in Great Britain. Soc Sci Med 1985;20:753-9.

8 Hinton J. A comparison of places and policies for terminal care. Lancet 1979;i:29-32.

9 Parkes CM. Terminal care: evaluation of an advisory domiciliary services at $\mathrm{St}$ Christopher's Hospice. Postgrad Med f 1984;60:120-4.

10 Mor V, Greer DS, Kastenbaum R. The hospice experiment. Baltimore: John Hopkins University Press, 1988

11 Anonymous. Hospice comes of age [Editorial]. Lancet 1986;i: 1013-4

12 Higginson I, Wade A, McCarthy M. A comparison of four outcome measures of terminal care. In: Gilmore A, Gilmore S, eds. A safer death. New York: Plenum Press, 1988:205-11. 
13 Higginson I, McCarthy M. Measuring symptoms in terminal care: are pain and dy'spnoea controlled? I R Soc Med 1989;82:264-7.

4 Cartwright A, Hockey L, Anderson JL. Life before death. London: Routledge and Kegan Paul, 1973.

15 Sprent P. Applied nonparametric statistical methods. London: Chapman and Hall, 1989.

16 Fleiss JL. The measurement of interrater agreement. In: Statistical methods for rates and proportions. New York: Wiley, 1981:212-23.

17 Parkes $\mathrm{CM}$. Home or hospital? Terminal care as seen by surviving spouses. JR Coll Gion Pract 1978:28:19-30.

Higginson I, Chandler S, Dixon P, Wade A, McCarthy M. Analgesics and symptom control in cancer patients referred to the Bloomsbury Terminal symptom control in cancer patients referred to the Bloomsbury Terminal
Care Support Team. In: Twycross RG, ed. Edinburgh symposium on pain Care Support Team. In: Twycross RG, ed. Edinburgh symposium on pain
control and medical education. London: Royal Society of Medicine, 1989: 217-22. (International congress and symposium series 149.)
19 Gilley J. Intimacy and terminal care. f R Coll Gen Pract 1988:38:121-2.

20 Barnett $M$, McCarthy $M$. Identification of terminally ill patients in the community. In: Doyle D, ed. 1986 Internation symposium on pain control. London: Roval Society of Medicine, 1987:78-80. (International congress and symposium series 123 .)

21 Mount BM, Scott JF. Whither hospice evaluation? $f$ Chronic Dis 1987; $40: 545-53$.

22 Doyle D. Education in palliative medicine and pain therapy: an overview. In: Twycross RG, ed. Edinburgh symposium on pain control and medical education London: Royal Society of Medicine, 1989:165-74. (International congress London: Royal Society of

23 Maguire P, Faulkner A. Communicating with cancer patients. 1. Handling bad news and difficult questions. Br Med $\mathcal{F}$ 1988;297:972-4.

Accepted 9 May 1990

\title{
Lesson of the Week
}

\section{Impaired healing of neuropathic foot ulcers due to neuropathic bladder distension in a patient with diabetes}

\author{
Ewan A Masson, Ian A MacFarlane
}

Occult distension of the bladder may cause oedema and persistence of neuropathic ulcers in patients with diabetes
Department of Diabetes and Endocrinology, Walton Hospital, Liverpool L9 1AE

Ewan A Masson, MD, senior registrar in diabetes and endocrinology

Ian A MacFarlane, $\mathrm{MD}$, consultant physician

Correspondence to: Dr Masson.

BrMed f 1990;301:281
Foot ulcers in patients with diabetes have several well recognised causes, including somatic neuropathy, autonomic neuropathy, abnormal stress patterns, and vascular disease. ${ }^{1}$ Peripheral oedema, whether neuropathic or from another cause, may also play a part. ${ }^{12}$ Overdistension of the bladder can cause pressure on the iliac veins and lead to oedema of the legs, ${ }^{3}$ and distension of the bladder due to autonomic neuropathy in diabetes has been reported to cause oedema of the legs mimicking deep .venous thrombosis. ${ }^{4}$ We report on a patient who had bilateral Charcot's arthropathy, oedema, and massive foot ulceration that was resistant to treatment. Correction of occult distension of the bladder led to resolution of the oedema and healing of the ulcers.

\section{Case report}

A 69 year old woman had had non-insulin dependent diabetes for 18 years, which was treated with oral chlorpropamide. She presented to the clinic in 1987 with a three year history of bilateral plantar foot ulceration and a five year history of Charcot's arthropathy. She also had severe proliferative retinopathy requiring laser photocoagulation. Serum creatinine concentration was normal $(90 \mu \mathrm{mol} / \mathrm{l})$, but she had persistent albuminuria ( ++ on dipstick testing). She had chronic leg oedema that was not associated with cardiac failure, hypoalbuminaemia (serum albumin concentration $38 \mathrm{~g} / \mathrm{l}$ ), or obvious local venous abnormality. Treatment with frusemide was only partly successful in reducing the oedema.

Over the next two years her foot ulcers persisted despite treatment with bed rest and daily dressing by the district nurse. Attempts at split skin grafting and total contact casting were unsuccessful. During this time she spent nearly six months as an inpatient. In 1989 the ulcers each measured $8 \times 8 \mathrm{~cm}$. Her serum creatinine concentration was $202 \mu \mathrm{mol} / \mathrm{l}$, and she had occasional urinary incontinence. After catheterisation
$1500 \mathrm{ml}$ residual urine was obtained. Ultrasound scans confirmed considerable distension of the bladder with associated hydronephrosis. A neurogenic bladder was diagnosed.

On discharge she was fitted with a long term catheter and her leg oedema, which had been present for at least four years, resolved over the next few weeks. The foot ulcers healed over the next five months without further specific treatment

\section{Discussion}

Leg oedema as a result of overdistension of the bladder has been reported in non-diabetic ${ }^{3}$ and diabetic patients, ${ }^{4}$ with rapid resolution after urinary catheterisation. The mechanism is thought to be compression of the common iliac veins in the pelvis. In this case the distension of the bladder, presumed to be due to autonomic neuropathy, may have been present for several years before its diagnosis. The resolution of the oedema after catheterisation suggests that the distension caused the oedema. Oedema of the foot has been suggested to be an important predisposing factor in foot ulceration regardless of its aetiology, and increased venous pressure may retard healing.

Diabetic patients with neuropathic foot ulcers resistant to treatment should have ultrasonography of their pelvises to exclude distension of the bladder, particularly if leg oedema is present.

1 Young RJ. Identification of the subject "at-risk" of foot ulceration. In: Connor $\mathrm{H}$, Boulton AJM Ward JD, eds. The foot in diabetes. Chichester: John Wiley, 1987:1-10.

2 Edmonds ME, Blundell MP, Morris ME, Thomas EM, Cotton LT, Watkins PJ. Improved survival of the diabetic foot: the role of a special foot clinic. Qf Med 1986;60:763-71

3 Mulcahy JJ, Bivins BA. Leg edema as complication of bladder overdistension. Urology 1979;13:564-7.

4 Jennings AM, Walker M, Ward JD. Diabetic neuropathic bladder associated with clinical features of iliofemoral venous thrombosis. Diabetic Med 1988;5:391-2.

(Accepted 25 April 1990) 